\title{
Editorial
}

\section{Making sense of curriculum}

\begin{abstract}
Jane Abbiss
First, as the new editor of Curriculum Matters, it seems appropriate that I introduce myself. In doing this, I recognise that I make sense of curriculum and curriculum conversations through academic engagement and my own lived curriculum experiences. It is therefore important that I give readers an idea of my background and interests in curriculum.

I am a senior lecturer in the College of Education, University of Canterbury. As a teacher educator, academic, and researcher, and with a background as a secondary school teacher, I would describe myself as having a "hybrid identity" (Davey, 2013) that crosses education boundaries. With a personal and professional commitment to teaching and teacher education, I have long thought that curriculum and conversations about curriculum issues are important. Over the last 25 years I have experienced and had to respond in my teaching to major curriculum and assessment reforms, including the development and implementation of the National Certificate of Educational Achievement (NCEA) and The New Zealand Curriculum (NZC) (Ministry of Education, 2007). I have been frustrated by organisational reform and the institutional separation of curriculum and assessment that seemed to me to ignore an intimate connection between the two by positioning assessment as somehow "not curriculum". I have observed tensions and felt personally conflicted as I have negotiated to what extent my role is to implement the national curriculum and assessment requirements, or to resist, critique, and challenge the curriculum. These personal negotiations are ongoing.
\end{abstract}

Engagement with curriculum theory has helped me to make sense of my experiences of curriculum and curriculum reform. It has helped me to understand intellectually what happens in the process of curriculum change-which is not to claim that my understanding is the only possible interpretation and way of viewing curriculum change. Ideas that resonate with me and have helped me with my sense-making include the following. 


\section{Editorial}

- The political nature of curriculum, and the importance of not separating curriculum from the structures and wider political changes within which it is embedded (Hargreaves, 1989; Roberts, 2003).

- The idea that an ideological and hidden curriculum operates in schools and various educational settings, where things are learned that may not be intended and where norms, values, and beliefs are consciously and unconsciously conveyed through social interactions and organisational structures (Giroux, 1979).

- An understanding that different assumptions and conflicting expectations are held by people about the roles of teachers as "curriculum implementers" and "curriculum designers". In the first of these roles, teachers are held responsible for the implementation the official curriculum and the execution of assessment procedures. In the second, they are positioned as active in curriculum design as they interpret, reconstruct and co-construct curriculum in context and practice (Elliott, 1998; McGee, 1997).

- The idea that curriculum reflects contestable claims about what is worth knowing (Pinar, 2012).

I take a broad view of curriculum inquiry that encompasses, and is not limited to, policy studies, research relating to classroom practice and pedagogy, discipline-based inquiries, programme evaluation, and theoretical envisioning of new or different ways of thinking about and understanding curriculum.

\section{Importance of Curriculum Matters}

The title of this journal, Curriculum Matters, signals that the content of the journal relates to curriculum themes and debates and it suggests that explorations of curriculum issues are important. Concern with curriculum matters, though, is not confined to educators. A quick scan of recent media headlines suggests that curriculum issues are of popular interest-or are deemed by editors to have popular appeal. For example:

- Psychology is out in the curriculum cold (Nelson Mail, 3 July 2013)

- Six things Kiwi kids should learn (Stuff Nation, Reader Report 21 July 2013) 
- Let's bring knowledge back into schools (New Zealand Herald, 7 September 2013)

- Parata's U-turn on charter school creationism (3 News, 19 September 2013)

- Schools put science in too-hard basket (Dominion Post, 23 September 2013)

- Injecting street culture into the school curriculum (Waikato Times, 1 October 2013)

Such headlines present particular opinions and focus on specific aspects of curriculum, but they also relate to a core question in curriculum studies: "What knowledge is of most worth?" (Pinar, 2012, p. xv). This question invites conversations about: the nature of knowledge and pedagogies in particular disciplinary contexts; the contestability of knowledge and ways in which some disciplines or learning areas are to deemed to be of greater or lesser worth; who gets to choose what is worth knowing and how this is decided in particular social and political contexts; and how political structures and ideological positions make some curriculum developments possible and preclude others. I see Curriculum Matters as a vehicle for these conversations.

Curriculum does matter. It matters to the children, young people, and adults who every day attend early childhood centres, schools, and tertiary institutions and for whom curriculum is integral to their educational experiences. It matters to their parents, caregivers, whānau, and communities who witness the educational engagement and disaffection of their children at different levels in the education system. It matters to teachers, educational leaders, and teacher educators, who daily negotiate the political landscape of curriculum policy and change. And it matters to academics who theorise curriculum and whose work helps to deepen and broaden the research base for curriculum studies.

\section{This collection}

This ninth issue of Curriculum Matters is an eclectic collection of academic articles that explore a range of curriculum issues. The contexts include early childhood, primary, secondary, and tertiary education. The 


\section{Editorial}

contributing authors address issues and raise questions pertaining to curriculum in Aotearoa New Zealand and more broadly.

The first two articles explore the nature of knowledge, teaching and learning in particular subject contexts in schools. Mike Taylor and Azra Moeed explore how geography and science teachers responded to the Canterbury earthquakes. They describe different responses made to disaster education in relation to the Canterbury earthquakes, from teacher and student perspectives, and identify differences between the types of knowledge and learning around earthquakes that was encouraged by geography and science teachers. This is seen to reflect both the defining and constraining influences of discipline, curriculum and assessment structures, and the creative agency of teachers.

Rachel Tallon examines the changing and diverse media landscape of the Internet and the challenges this presents for teaching and learning about current events in social studies classrooms. Focusing on the use of current-events quizzes, she argues that these are restrictive and do not reflect the fluidity of news in the digital era. Use of quizzes may be counterproductive and discouraging for young people who receive their news from a wide variety of sources. She advocates for a critical literacy approach to current events teaching in social studies, to encourage students to think about sources of news and to empower students to actively and critically engage with the news.

The third article, by Margaret Kitchen, focuses on stories of learner experiences. She describes the struggles of New Zealand-educated Korean students transitioning from New Zealand primary schools to secondary schools, as described by their parents. She highlights the identity challenges experienced by these students in making and retaining cross-cultural friendship at secondary school as they find themselves increasingly drawn away from kiwi friendship groups and into international student networks. This contrasts with their experiences of more integrated primary school communities. Schools are invited to consider how their structures may act to socially include or exclude multilingual students.

The next three articles focus on initiatives in initial teacher education (ITE) and the learning experiences of preservice teachers. Lyn Lewis 
explores how she, a teacher educator, worked with a group preservice teachers to see how social sciences may be used as a vehicle for developing key competencies-focusing on managing self, relating to others and participation and contribution. This was done by embedding the key competencies in a social sciences curriculum paper, as part of the learning processes and through which preservice teachers learnt about the relationship between the key competencies and social sciences teaching and learning. Conclusions are drawn that support an embedded relationship between key competencies and curriculum learning in initial teacher education.

Steven Sexton (teacher educator), Ruby Facer, and Courtney Ross (preservice teachers), report on how Ruby and Courtney developed understanding of the nature of science and meaningful learning in science in their ITE course. This was achieved through engagement with the Building Science Concepts series of books and the Nature of Science strand in NZC. A case is made that the Building Science Concepts series can be adapted to reflect intentions of $N Z C$ and that the series remains relevant for preservice teachers who are learning about science and how to teach science in ways that are engaging and meaningful for students in classrooms.

Sue Wilson and Jane McChesney describe the dilemmas and complexities encountered in navigating the curriculum and school mathematics landscapes by a group of Year 3 primary preservice teachers. Two metaphors, "navigating" and "noticing", are used to describe the journeys of these teachers as they tried to make sense of a complex array of curriculum materials and planned for mathematics learning. They argue that deliberate engagement with curriculum materials and opportunities to engage in comprehensive planning processes in ITE are empowering for preservice teachers. Also, they suggest that guided participation in curriculum design is important for novice teacher development, but that such opportunities are difficult to sustain in the face of shifting priorities for teacher education.

Following on from these, two articles focus on education policy and implications for practice in different sectors. Bradley Hannigan examines the theory and nature of scientific management in education and argues 


\section{Editorial}

that there is a risk to early childhood education (ECE) from the trend towards scientific management in education that emphasises curriculum prescription, standardisation, measurement, and performance evaluation. He argues that recent policy and legislative changes signify a move towards scientific management in ECE and the normalisation of scientific management across early childhood and compulsory schooling sectors. He cautions that an increase in scientific management in ECE is likely, while also suggesting that teacher recognition of the discourse of scientific management in ECE is a precursor to challenging this discourse.

Amy Chakif examines the curriculum policy landscape relating to mathematics education and presents the stories of how two primary school teachers have enacted curriculum policies in practice. Policies considered include $N Z C$, the numeracy development projects, and the numeracy National Standards. She finds that enacting curriculum policy in mathematics is challenging for the two teachers, which is attributed to the inconsistent and contradictory nature of mathematics curriculum policies. The teachers resolved contradictions in ways that were unique and which were influenced by their personal beliefs about mathematics teaching and learning. In light of these findings, the effectiveness of across-schools moderation tools for mathematics assessment is questioned.

In the concluding article of the collection, Margaret McLean and Frances Hartnett describe a tertiary level diploma course that was intentionally developed to challenge hegemonic understandings associated with the rehabilitation of intellectually disabled offenders. The course participants were care co-ordinators and care managers. The potential of the curriculum (designed and enacted in a particular course) to be counter-hegemonic is examined in relation to curriculum theory, paradoxes inherent in the relevant New Zealand legislation and student feedback on the course. It is suggested that educational institutions can make a valuable contribution to upholding the rights of disabled young people, through curriculum design that challenges the consequences of normalcy and the privileging of some and marginalising of others.

Jane Abbiss

Editor 


\section{References}

Davey, R. (2013). The professional identity of teacher educators: Career on the cusp? London: Routledge.

Elliott, J. (1998). The curriculum experiment: Meeting the challenge of social change. Buckingham: Open University Press.

Giroux, H. \& Penna, A. (1979). Social education in the classroom: The Dynamics of the hidden curriculum. Theory and Research in Social Education, 7(1), 21-42.

Hargreaves, A. (1989). Curriculum and assessment reform. Milton Keynes: Open University Press.

McGee, C. (1997). Teachers and curriculum decision-making. Palmerston North: Dunmore Press.

Ministry of Education. (2007). The New Zealand curriculum. Wellington: Learning Media.

Pinar, W. (2012). What is curriculum theory?(2nd edition). New York: Routledge.

Roberts, P. (2003). Contemporary curriculum research in New Zealand. In W. Pinar (Ed.). International Handbook of Curriculum Research (pp. 495-516). Mahwah, NJ: Lawrence Erlbaum Associates. 